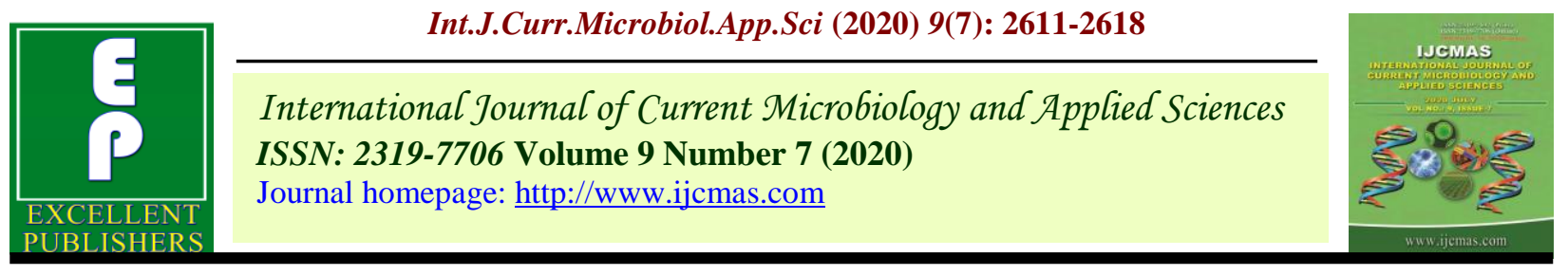

Original Research Article

https://doi.org/10.20546/ijcmas.2020.907.308

\title{
Isolation and Screening of Plastic Degrading Bacteria from Dumping Sites of Solid Waste
}

\author{
Kavita Rana* and Neerja Rana \\ Department of Basic Sciences, College of Forestry, University of Horticulture and Forestry, \\ Nauni, Solan 173230, India \\ *Corresponding author
}

A B S T R A C T

Keywords

Plastic degrading bacteria, Dumping sites, Solid waste

Article Info

Accepted:

22 June 2020

Available Online:

10 July 2020
Soil samples were collected from various dumping sites of five (5) districts i.e. Solan, Bilaspur, Hamirpur, Mandi and Kangra of Himachal Pradesh. The soil samples were used for isolation of plastic degrading microorganism on M9 media enriched with Polyethylene glycol as sole carbon source. Twenty three (23) isolates have been isolated using two concentrations of Polyethylene glycol (PEG) i.e. 0.5 percent and 1 percent. The incubated plates further treated with Coomassies blue Rg-250 dye to observe the zone of clearance. Out of 23 isolates on the basis of zone of clearance two (2) isolates were selected as elite plastic degraders viz., PDBH1 and PDBM 2 for further investigation.

\section{Introduction}

Under the natural condition degradable or non-degradable organic materials are considered as the major environmental problem, e.g. plastics. The accumulation of these plastic wastes created serious threat to environment and wildlife. The environmental concerns include air, water and soil pollution. The dispersal of urban and industrial wastes contaminates the soil. The soil contaminations are mainly occurring by human activities. Environmental pollution is caused by synthetic polymers, such as wastes of plastic and water soluble synthetic polymers in wastewater (Shrestha et al., 2019). The proliferation rate of plastic materials is very fast, and the environment is affected by such wastes throughout the world. Plastic waste in the form of litter enters running water in different ways according to nature and ultimately contaminates the environment. Plastic waste causes eight intricate problems in the environment: (1) plastic trash pollutes, (2) plastic entangles marine life, (3) ingestion of plastic items, (4) biodegradation of petroleum-based plastic polymers is timeconsuming, (5) broken plastic and its pellets disturb the Food web, (6) interference with sediment inhabitants, (7) litter destroying the 
primary habitat of new emerging life and (8) plastic litter causes major damage to vessels (Singh et al., 2014).

Plastics are made up of linking of monomers together by chemical bonds. Polythene comprises of 64 per cent of total plastic, which is a linear hydrocarbon polymers consisting of long chains of the ethylene monomers. General formula of polyethylene is $\mathrm{C}_{n} \mathrm{H}_{2 n}$, where " $\mathrm{n}$ " is the number of carbon atoms (Shreshtha et al., 2019). The plastics we use today are made from inorganic and organic raw materials, such as carbon, silicon, hydrogen, nitrogen, oxygen and chloride. The basic materials used for making plastics are extracted from oil, coal and natural gas. Plastics include polythene, propylene, polystyrene, polyurethane, nylon etc. (Rosario and Baburaj, 2017). Polyethylene either LDPE (low density polyethylene) or HDPE (high density polyethylene) is a thermoplastic polymer made by monomers of ethylene, used mostly as thin films and packaging sheets (Bhardwaj et al., 2012).

In this context microbe has been identified as plastic degraders. Microbes are efficient plastic degraders as they can form slimy layer called as biofilm over the plastic and use it as sole carbon source to gain nourishment and growth. The surface of the cell are hydrophobic that aids the degradation of the polyethylene (Pratiksha et al., 2019). These microbial colonies cleave the polymer firstly into oligomer then to dimer to monomers which is due to secretion extracellular enzyme (Shimao, 2001).

\section{Materials and Methods}

\section{Sampling}

In the survey dumping sites from each district were marked at different places in Himachal Pradesh: UHF Nauni, Palampur, Mandi,
Ghuwarwin and Bajuri. The data of altitude, longitude and latitude with GPS coordinates was given in the Table 1. Soil samples were collected from the marked areas (Plate 1) and analysed for their physicochemical properties (Jumaah, 2017).

\section{Isolation of bacteria isolates}

Soil samples were collected from the dumping sites of selected districts of Himachal Pradesh. Ten-fold serial dilution was prepared by taking $1 \mathrm{~g}$ of soil sample into $10 \mathrm{ml}$ of sterile distilled water and mixed well to get soil suspension. $1 \mathrm{ml}$ of soil suspension was diluted with $9 \mathrm{ml}$ of sterile distilled water making the dilution to $10^{-2}$. Similarly dilution up to $10^{-8}$ was made separately for each soil sample. Suspension $(0.1 \mathrm{ml})$ of soil extract was prepared from $10^{-3}$ to $10^{-8}$ dilutions and inoculated into sterile M9+ PEG plates. The sample was spread throughout the media plates and inoculated Petri plates were incubated for 4-7 days in an incubator at $37^{\circ} \mathrm{C}$ (Singh et al., 2015).

\section{Screening of bacteria isolates}

Screening of obtained isolates was carried out on M9 media enriched with Polyethylene glycol. After completion of incubation time the plates were stained with $0.1 \%$ Coomassie blue R-250 in 40 per cent methanol and 10 per cent acetic acid for 20 minutes. After staining, the plates were destained with 40 per cent methanol and 10 per cent acetic acid $(\mathrm{v} / \mathrm{v})$ for another 25 minutes. The bacterial isolates that showed zone of clearance were selected for further study (Rosario and Baburaj, 2017).

\section{Morphological identification}

The morphological and biochemical analysis was carried out for the bacterial isolates. The isolates were examined for their morphology, 
color, size and shape, margin, cell arrangement (Jumaah, 2017).

\section{Results and Discussion}

\section{Variability in physicochemical properties of soil samples}

The $\mathrm{pH}$, electrical conductivity (EC), organic carbon matter and microbial count of the soil sample were analyzed as presented in Table 2 . The $\mathrm{pH}$ of soil samples ranged from 6.5 to 7.2. The electrical conductivity (EC) ranged between $1.0 \mathrm{ds} / \mathrm{m}$ to $1.6 \mathrm{ds} / \mathrm{m}$ whereas organic carbon varied between 1.4 percent and 1.8 percent. The perusal of the data presented in Table 2 showed that there is variability in the microbial count may be due to the physicochemical properties of the soil sample. The decomposing site always have acidic $\mathrm{pH}$ but due to microbial activities on different kind of accumulation of organic and inorganic waste, the $\mathrm{pH}$ may shift from acidic to neutral (Wang et al., 2013).

The highest microbial count was observed in Mandi with $\mathrm{pH} 7.0\left(257 \times 10^{8}\right)$ followed by Hamirpur district with $\mathrm{pH} 7.3\left(255 \times 10^{8}\right)$ and then by Bilaspur district with $\mathrm{pH} 7.2$ $\left(248 \times 10^{8}\right)$, and minimum was recorded in Kangra district $\left(219 \times 10^{8}\right)$. The microbial biomass so observed confers that the surface soil sample has more active plastic degrading microorganism as it has more organic waste content (Borutaet al., 2016, Wahsha et al., 2017). The results are in agreement with Begum et al., 2015 Deeepika and Madhuri (2015) and Usha et al., (2011) who reported microbial association in plastic degradation from soil samples contaminated with plastic. They also confers that microbial population initially adheres to plastic and then slowly utilize for their nourishment and growth which leads to degradation of polyethylene generally known as plastic.
Isolation of microorganism from soil samples of dumping sites of Himachal Pradesh

The dumping sites are the most suitable regions for the collection as they are rich in plastic and other nutrients required for microbial flourishing. The variation in population level of microflora associated with collected soil sample from five districts is summarized in Table 3 and Fig 1. Isolation was made from the collected soil samples as the data in the Table 3 reveals that Hamirpur districts has the highest number of microbial isolates i.e. six (Two fungi + four bacterial colonies) followed five isolates from Mandi (one fungi +4 bacterial colonies) and Solan (two fungi + three bacterial colony) district. Our results are in agreement with Ruslan et al., (2018) who obtained sixteen (16) bacterial isolates on nutrient agar from soil samples which were able to degrade polysterene plastic. Similarly, Pratiksha et al., (2019) isolated Bacillus subtilis from soil samples of dumping site that has capability of degrading low and high density plastic.

\section{Screening on Polyethylene glycol (PEG)}

In qualitative screening, bacterial isolates were subjected for the utilization of polyethylene glycol (PEG) as sole carbon source to form zone of clearance. The data presented in Table 4 reveals that among the 6 isolates of Hamirpur, PDBH 3 and 5 isolates of Mandi districts PDBM2 has the highest zone of clearance on both 0.5 percent and 1 percent concentration of PEG. The fewer zones were shown by three isolates from Solan, two from Kangra and one from Bilaspur district. However, 3 isolates from Bilaspur, 2 from Hamirpur and 1 isolate from Solan do not exhibit any zone of clearance. The screening study of all the isolates revealed that PDBH3 and PDBM 2 were potent PEG utilizers (Plate 2), thus selected 
for further studies. The results are in accordance with Botre et al., (2015) who provide 0.1 per cent LDPE (Low Density Polyethylene) powder as sole carbon source and observed clear zone around the microbial colonies. Divyalakshmi and Subhashini (2016) screened plastic degrading bacteria from various soil samples. They reported growth on minimal salt agar medium with polyethylene as sole carbon source. Sriyapai et al., (2018) who depicted zone of clearance by polyester degrading thermophilic bacteria isolated from compost soil.

Table.1 Dumping sites of solid waste in Himachal Pradesh

\begin{tabular}{|c|l|l|l|l|l|}
\hline $\begin{array}{l}\text { Name of } \\
\text { location }\end{array}$ & District & $\begin{array}{c}\text { Altitude } \\
(\mathbf{m s l})\end{array}$ & Latitude & Longitude & Collection site \\
\hline UHF Nauni & Solan & 1265 & $30^{\circ} 51^{\prime} 44.47^{\prime \prime} \mathrm{N}$ & $77^{\circ} 10^{\prime} 8.91^{\prime \prime} \mathrm{E}$ & City dumping site \\
\hline Palampur & Kangra & 1472 & $32^{\circ} 10^{\prime} 97.22^{\prime \prime} \mathrm{N}$ & $76^{\circ} 53^{\prime} 66.41^{\prime \prime} \mathrm{E}$ & City dumping site \\
\hline Bindravani & Mandi & 760 & $31^{\circ} 42^{\prime} 25^{\prime \prime} \mathrm{N}$ & $76^{\circ} 55^{\prime} 54^{\prime \prime} \mathrm{E}$ & City dumping site \\
\hline Ghuwarwin & Bilaspur & 262 & $22.09^{\circ} \mathrm{N}$ & $82.15^{\circ} \mathrm{E}$ & City dumping site \\
\hline Bajuri & Hamirpur & 989 & $31.68^{\circ} \mathrm{N}$ & $76.52^{\circ} \mathrm{E}$ & City dumping site \\
\hline
\end{tabular}

Table 2: Different soil parameters analysis

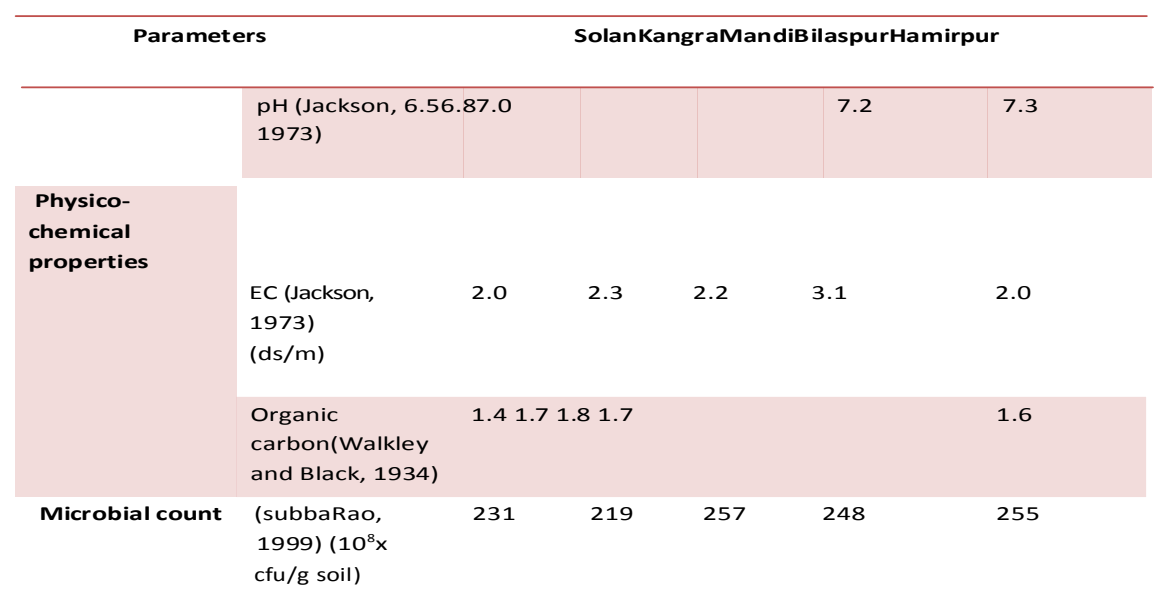

Table.3 Isolates from different dumping sites of Himachal Pradesh

\begin{tabular}{|l|c|}
\hline District & Number of Isolates \\
\hline Solan & $\mathbf{5}$ \\
\hline Bilaspur & $\mathbf{4}$ \\
\hline Hamirpur & $\mathbf{6}$ \\
\hline Kangra & $\mathbf{3}$ \\
\hline Mandi & $\mathbf{5}$ \\
\hline Total & $\mathbf{2 3}$ \\
\hline
\end{tabular}


Table.4 Qualitative screening via Zone of clearance of the selected isolates from selected dumping sites of Himachal Pradesh

\begin{tabular}{|c|c|c|c|c|}
\hline Sr. No. & District & Isolate & $\begin{array}{c}\text { Zone of Hydrolysis ( } 0.5 \% \\
\text { PEG) }\end{array}$ & $\begin{array}{c}\text { Zone of Hydrolysis } \\
\text { (1\% PEG) }\end{array}$ \\
\hline \multirow[t]{5}{*}{1} & Solan & PDBS1 & + & + \\
\hline & & PDBS2 & + & + \\
\hline & & PDBS3 & + & + \\
\hline & & PDBS4 & - & - \\
\hline & & PDBS5 & + & - \\
\hline \multirow[t]{4}{*}{2} & Bilaspur & PDBB1 & - & - \\
\hline & & PDBB2 & - & - \\
\hline & & PDBB3 & - & - \\
\hline & & PDBB4 & + & - \\
\hline \multirow[t]{6}{*}{3} & Hamirpur & PDBH1 & ++ & ++ \\
\hline & & PDBH2 & + & + \\
\hline & & PDBH3 & +++ & +++ \\
\hline & & PDBH4 & + & + \\
\hline & & PDBH5 & - & - \\
\hline & & PDBH6 & - & - \\
\hline \multirow[t]{3}{*}{4} & Kangra & PDBK1 & + & + \\
\hline & & PDBK2 & + & + \\
\hline & & PDBK3 & ++ & ++ \\
\hline \multirow[t]{5}{*}{5} & Mandi & PDBM1 & ++ & ++ \\
\hline & & PDBM2 & +++ & +++ \\
\hline & & PDBM3 & + & + \\
\hline & & PDBM4 & + & + \\
\hline & & PDBM5 & + & + \\
\hline
\end{tabular}

Where,

\begin{tabular}{|l|l|}
\hline- & No clearance \\
\hline+ & Minimum clearance \\
\hline++ & Moderate clearance \\
\hline+++ & Maximum clearance \\
\hline
\end{tabular}

Table.5 Morphological characteristic of Plastic Degrading Bacterial isolates

\begin{tabular}{|l|l|l|l|l|l|}
\hline \multirow{2}{*}{ S.No. } & \multirow{2}{*}{ Morphotypes } & \multicolumn{4}{|c|}{ Colony Morphology } \\
\cline { 3 - 6 } & & Forms elevation & Elevation & Margin & Color \\
\hline 1 & PDBS1 & Plantiform & Flat & Entire & Creamish \\
\hline 2 & PDBS2 & Circular & Raised & Entire & Yellow \\
\hline 3 & PDBS3 & Irregular & Flat & Entire & White \\
\hline 4 & PDBS4 & Circular & Flat & Entire & Creamish \\
\hline 5 & PDBS5 & Irregular & Flat & Undulate & White \\
\hline 6 & PDBB1 & Circular & Raised & Undulate & White \\
\hline 7 & PDBB2 & Circular & Raised & Entire & Creamish \\
\hline 8 & PDBB3 & Circular & Raised & Entire & Yellow \\
\hline 9 & PDBB4 & Plantiform & Flat & Entire & Yellow \\
\hline 10 & PDBH1 & Circular & Raised & Entire & Creamish \\
\hline 11 & PDBH2 & Plantiform & Flat & Entire & Creamish \\
\hline 12 & PDBH3 & Circular & Flat & Entire & Yellow \\
\hline 13 & PDBH4 & Irregular & Flat & Entire & White \\
\hline 14 & PDBH5 & Circular & Raised & Entire & Creamish \\
\hline 15 & PDBH6 & Irregular & Raised & Undulate & White \\
\hline 16 & PDBK1 & Circular & Raised & Undulate & White \\
\hline 17 & PDBK2 & Circular & Flat & Entire & Yellow \\
\hline
\end{tabular}


Fig.1 Depicting number of isolates from dumping sites of Himachal Pradesh

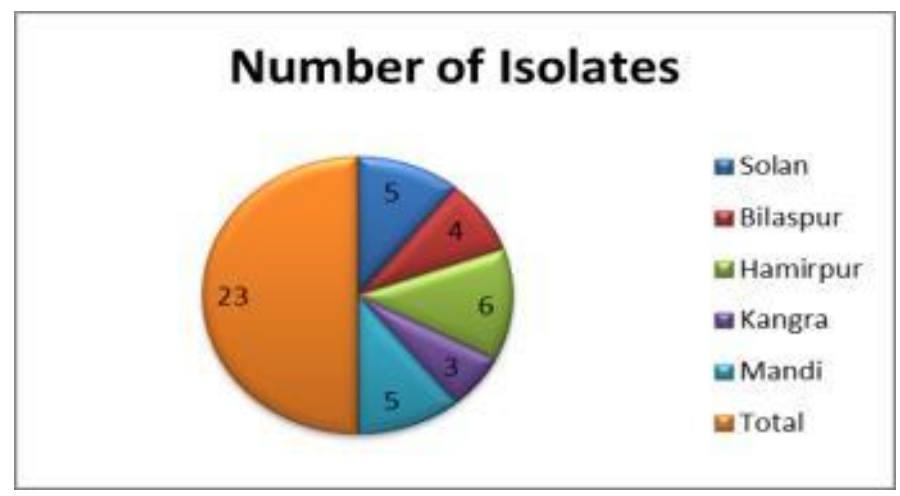

Plate.1 Representative collection sites of soil from solid waste
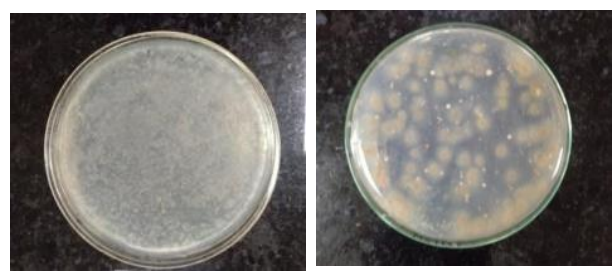

Plate.2 Diversity of microflora in (a) Hamirpur and (b) Mandi districts
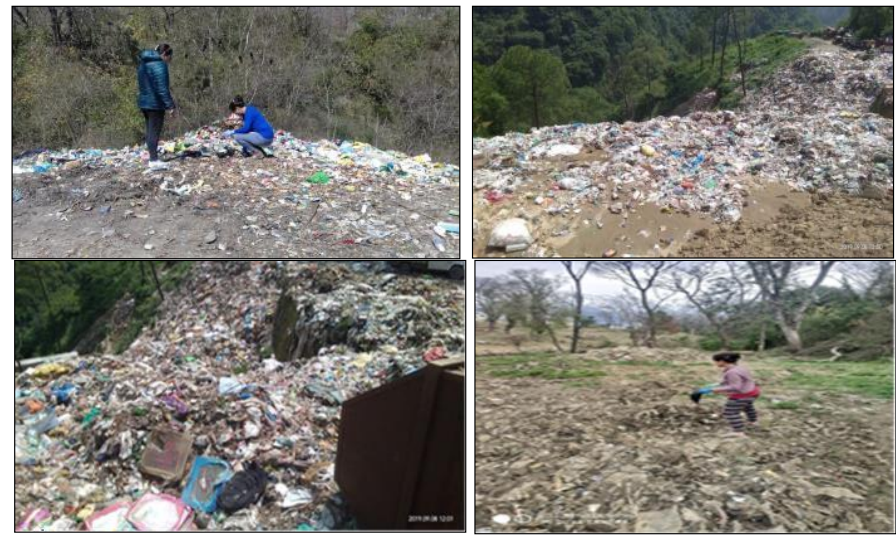

Plate.2 Degradation by PDBH3 (a) and PDBM 2 (b)

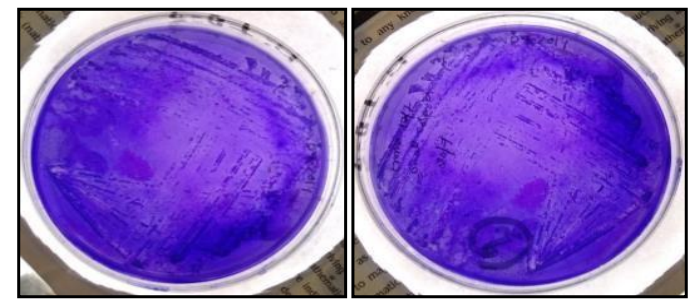

a

b 
Morphological characteristics of bacterial isolates from five dumping sites of Himachal Pradesh

All the twenty three isolates were examined for their morphological characteristics. It was recorded that the isolates varied from plantiform form to circular and irregular as depicted in Table 5. The colour of the colonies varied from white to yellow having flat and raised elevation to entire and undulate margins. The selected isolate PDBH 3 was circular in form having flat elevation with entire margin and creamish colour whereas PDBM 2 was irregular in shape having entire margin and white colour.

These results are in agreement with Vignesh et al., (2016) observed three isolate and reported that one was spherical in shape while other two were rods and varied from white to greyish in color. Soud (2019) who examined the bacterial colonies under microscope and found that colony color ranged from grey to white and yellow and the shape was spherical of all the isolates.

In conclusion, the diversity of bacterial colonies was observed at different dumping sites of Himachal Pradesh. It was observed that environment plays a very vital role in the activity of plastic degraders as the diversity obtained from different districts were varied among five districts. The selected bacterial isolates were efficient degraders of LDPE over the time course of 45 days. It is better to form a consortium rather to go for individual strain for better degradation. The ability to degrade polymers depends on the enzymes produced by the microbes to convert the polymers to oligomers and then to monomers. These water soluble enzymatically cleaved products are further absorbed by the microbial cells as carbon source where they are metabolized.

\section{Acknowledgement}

Himachal Pradesh Council for Science, Technology \& Environment (HIMCOSTE) Shimla has been acknowledged by the author for providing financial assistance

\section{References}

Begum, M. A., Varalakshmi, B., and Umamagheswari, K. (2015). Biodegradation of polythene bag using bacteria isolated from soil. Int J Curr. Microbiol App Sci, 4(11), 674-680.

Bhardwaj, H., Gupta, R., and Tiwari, A. (2012). Microbial population associated with plastic degradation. Scientific reports, 5, 272-274.

Botre, S., Jadhav, P., Saraf, L., Rau, K., and Wagle, A. (2015). Screening and Isolation of Polyethylene degrading Bacteria from various sources. Int Res J Environmental Sci, 4(11), 58-61.

Boruta, BB., Lemanowicz, J., and Bartkowiak, A. (2016). Variation in biological and physicochemical parameters of the soil affected by uncontrolled landfill sites. Environmental Earth Sciences, 75(3), 201.

Deepika, S., and Madhuri, R. J. (2015). Biodegradation of low density polyethylene by micro-organisms from garbage soil. Journal of Experimental Biology and Agricultural Sciences, 3(1), 15-21.

Divyalakshmi, S., and Subhashini, A. (2016). Screening and isolation of polyethylene degrading bacteria from various soil environments. IOSR $J$ Environ SciToxicol Food Technol, 10(12),1-7.

Jumaah, OS. (2017). Screening of plastic degrading bacteria from dumped soil area, IOSR J. Environ. Sci. Toxicol. Food Technol, 11,93-98. 
Pratiksha. Y, Sudhruthi. L, Vignesh. V, Madhumita Ghosh Dastidar. (2019). Isolation, Identification and Analysis of Plastic Degrading Bacteria from Dumped Soil Area, International Journal of Pharmacy and Biological Sciences, 9,127-132.

Rosario, LLD., and Baburaj, S. (2017). Isolation and Screening of Plastic Degrading Bacteria from Polythene Dumped Garbage Soil, International Journal for Research in Applied Science and Engineering Technology, 5, 1028-1032.

Ruslan, R., and Permatadewi, A. Djama. (2018). Isolation and Characterization of Polystyrene-Degrading Bacteria Bacillus sp. ITP 10.1. 1 from Soil Sample of Jayawijaya Mountains, Papua, Indonesia. Int Res J Pharm, 9(10), 85-9.

ShresthaJk., Joshi DR., Regmi, P., and Badahit, G. (2019). "Isolation and Identification of Low Density Polyethylene (LDPE) Degrading Bacillus spp. from a Soil of Landfill Site". Acta Scientific Microbiology 2.4, 30-34.

Singh, J and Gupta, KC. (2014). Screening and Identification of Low density Polyethylene (LDPE) Degrading Soil Fungi Isolated from Polythene Polluted Sites around Gwalior city (M.P.), Int J CurrMicrobiol App Sci, 3(6): 443-448.

Singh, J., Gupta, KC., and Shrivastav, A. (2015). Isolation and identification of low density polyethylene (LDPE) degrading bacterial strains from polyethylene polluted sites around Gwalior city (M.P.), Journal of global biosciences, 4, 3220-3228.

Soud, S. A. (2019). Biodegradation of Polyethylene LDPE plastic waste using Locally Isolated Streptomyces sp. Journal of Pharmaceutical Sciences and Research, 11(4), 13331339.

Sriyapai, P., Chansiri, K., and Sriyapai, T. (2018). Isolation and characterization of polyester-based plastics-degrading bacteria from compost soils. Microbiology, 87(2), 290-300.

Usha, R., Sangeetha, T., and Palaniswamy, M. (2011). Screening of polyethylene degrading microorganisms from garbage soil. Libyan Agric Res Cent J Int, 2(4), 200-4.

Vignesh, R., Deepika, R. C., Manigandan, P., and Janani, R. (2016). Screening of plastic degrading microbes from various dumped soil samples. Int Res $J$ Eng Tech, 3(4), 2493-2498.

Wahsha, M., Nadimi-Goki, M., Fornasier, F., Al-Jawasreh, R., Hussein, E. I., and Bini, C. (2017). Microbial enzymes as an early warning management tool for monitoring mining site soils. Catena, 148,40-45.

Wang, Y., Tang, C., Wu, J., Liu, X., and Xu, J. (2013). Impact of organic matter addition on $\mathrm{pH}$ change of paddy soils. Journal of soils and sediments, 13(1), 12-23.

\section{How to cite this article:}

Kavita Rana and Neerja Rana. 2020. Isolation and Screening of Plastic Degrading Bacteria from Dumping Sites of Solid Waste. Int.J.Curr.Microbiol.App.Sci. 9(07): 2611-2618. doi: https://doi.org/10.20546/ijcmas.2020.907.308 